\title{
Origin of \& Solution to Global Financial Meltdown: An Islamic View
}

\author{
Md. Al-Mamun ${ }^{1} \&$ Md. Abdul Hanana $\mathrm{Mia}^{2}$ \\ ${ }^{1}$ Department of Business Administration, East West University, Dhaka, Bangladesh \\ ${ }^{2}$ Department of Management Information System, University of Dhaka, Dhaka, Bangladesh \\ Correspondence: Md. Al-Mamun, Department of Business Administration, East West University, Dhaka, \\ Bangladesh. Tel: 880-2-881-1381. E-mail: alm@ewubd.edu
}

Received: March 21, 2012 Accepted: April 16, 2012 Online Published: June 16, 2012

doi:10.5539/ijbm.v7n12p114 URL: http://dx.doi.org/ijbm.v7n12p114

\begin{abstract}
The meltdown of financial markets across the world is one of the most common characteristics of modern capitalist economy. Starting with the stock market crash of 1901 through the great depression of 1930s to the Black Monday of 1987, the Asian financial crisis of 1997 and finally the latest tsunami of global financial crisis, the history of major stock market crashes are undoubtedly a testimony of its nature. According to IMF, the world has witnessed more than 100 stock market crisis in last 30 years. However, with the endeavors of so many talented academicians, policymakers, and researchers the reasons behind these crashes still remain unexplored. After almost 25 years nobody has a solid answer to the reasons behind stock market crash in 1987. Meetings after meetings, summits after summits, conferences after conferences of the world leaders, thinkers and academicians in the form of DAVOS summit, G-8 summit, EU summits, G-20 summits etc. have failed miserably to identify the root causes behind the crisis. At times the expectations of finding a common solution to the problem from such high level summits have ended up with common blame-games while the crisis continues to multiply as various economies enters into much painful long term recessions with human stories of sufferings, job loss and even suicide. Therefore, this article aims at uncovering the root causes of repeated form of global financial crisis by critically investigating the philosophical and functional foundations of existing system of financial economy. A detailed review of fundamentals, methods and facts about capitalism clearly highlights the inevitability of such problem to exist in existing financial economic model in the light of Islamic economic system.
\end{abstract}

Keywords: capitalism, derivatives, financial economy, financial markets, Islamic economic system, real economy

\section{Introduction}

Roger Terry (1995, pp. 1-2) says, "The Americans know that there is a problem in America, but they do not know what it is, or why it is. More importantly, they do not know how to correct that problem. All they can do is to point at symptoms of the disease...In reality some of what are named solutions only make the problem worse, because these solutions attempt to change the results of the system without changing the system which has led to those results...The problem does not include the question of how we implement our economic system, for our economic system itself is the problem. The problem is in the foundational structure of our economic system, and partial solutions or bandaging the consequences is not a solution that will deal with the problem. If we want to reach our standards then we must weed out the problems from their roots and not merely clip some leaves. It is upon us to assess the foundations and assumptions on which our system is built and to expose it for what it really is (Note 1)."

Abraham Lincoln, the sixteenth American president, said, "...corporations have been enthroned and an era of corruption in high places will follow, and the money power of the country will endeavor to prolong its reign by working upon the prejudices of the people until all wealth is aggregated in a few hands and the Republic is destroyed (Note 2)." This is how the proponents of capitalism assess their own system.

Therefore, this logico-emperistic study will try to uncover the real reasons of financial markets meltdown by extensively reviewing the current system in its principles and its operations. Moreover focus will be given to understand the Islamic perspectives of these reasons and finally a brief summary on how Islamic model of financial system can help the world to be free from such corruptions of current practices, models and system. 


\section{A History of Stock Market Crash in Capitalism}

World's first stock-market crash happened in 1720, when the Mississippi Company-the Enron of its day-blew up. Even though Alan Greenspan, the former Chairman of the Federal Reserve of the United States, has described the current financial crisis as a "once-in-a-century credit tsunami", financial crisis in the capitalist economy is nothing new. A recent book, co-authored by Rogoff's Harvard colleague Robert Barro, has identified 148 crises since 1870 in which a country experienced a cumulative decline in GDP of at least 10 percent (Note 3). IMF has identified over 100 crises in last 30 years. They further added that financial crises seldom happen without inflicting pain on the wider economy; Ahmed M. (2008). Table 1 presents the major financial crashes in capitalist history. Indeed with the ongoing financial crisis, today many people are questioning the efficacy of free market enterprise system while many views the USA, leader of the capitalist world, as the world's new sick man (Note 4). A rescue package of $\$ 700$ billion in USA and around $£ 500$ billion in UK and similar additional staggering figures were not enough to save the fate of financial markets. Indeed, it just has multiplied the effects into the real economy. At the very outset of the meltdown, the collapse of capitalist iconoclasts like Lehman Brothers, nationalization of AIG, Freddie Mac, Fannie Mae, the takeover of Merrill Lynch and HBOS and the loss of stock market value by more than $65 \%$ tells how pervasive and serious the crisis is. This has also been echoed by president elect Barak Obama, as he puts it 'it will not just take one year or just one term to recover the loss due to the crisis'(Note 5). And what followed latter on with multiple rescissions in USA and Europe is nothing short of the Arab Spring in the street of USA, UK, Greece, Spain, Portugal, Ireland, French and many other countries. While the Arab springs overthrown the dictators one after another, global financial crisis did the same in Europe, French, Italy and Greece presents the three vivid examples.

Table 1. Major stock market crashes in USA

\begin{tabular}{lccccc}
\hline Period & Total days & Index & Starting index & Closing index & Change \\
\hline $09 / 09 / 2007$ to $09 / 09 / 2008$ & 365 & DJIA & 14,164 & 8,579 & $-40.00 \%$ \\
$01 / 15 / 2000$ to $10 / 9 / 2002$ & 999 & DJIA & $11,792.98$ & $7,286.27$ & $-37.80 \%$ \\
$19 / 07 / 1987$ to $19 / 01 / 1988$ & 180 & DJIA & 1738.74 & 1230.74 & $-24.61 \%$ \\
$1 / 11 / 1973$ to $12 / 06 / 1974$ & 694 & DJIA & 1051.7 & 577.6 & $-40.10 \%$ \\
$9 / 12 / 1939$ to $4 / 28 / 1942$ & 959 & DJIA & 115.92 & 92.92 & $-40.40 \%$ \\
$3 / 10 / 1937$ to $3 / 31 / 1938$ & 386 & DJIA & 194.4 & 98.95 & $-49.10 \%$ \\
$4 / 17 / 1930$ to $7 / 8 / 1932$ & 813 & DJIA & 294.07 & 41.22 & $-86.00 \%$ \\
$9 / 3 / 1929$ to $11 / 13 / 1929$ & 71 & DJIA & 381.17 & 198.69 & $-47.90 \%$ \\
$11 / 3 / 1919$ to $8 / 24 / 1921$ & 660 & DJIA & 119.62 & 63.9 & $-46.60 \%$ \\
$11 / 21 / 1916$ to $12 / 19 / 1917$ & 393 & DJIA & 110.15 & 65.95 & $-40.10 \%$ \\
$1 / 19 / 1906$ to $11 / 15 / 1907$ & 665 & DJIA & 75.45 & 38.83 & $-48.50 \%$ \\
$6 / 17 / 1901$ to $11 / 9 / 1903$ & 875 & DJIA & 57.33 & 30.88 & $-46.10 \%$
\end{tabular}

Source: Various pages of http://en.wikipedia.org/wiki/

\section{Literature Review: The Reasons \& Measures}

The financial crisis has been attributed to a number of factors pervasive in both housing and credit markets, factors which emerged over a number of years. In its "Declaration of the Summit on Financial Markets and the World Economy," dated 15 November 2008, leaders of the Group of 20 cited the following causes as "weak underwriting standards, unsound risk management practices, increasingly complex and opaque financial products, and consequent excessive leverage combined to create vulnerabilities in the system' (Note 6).

Apart from the general understanding of the reasons behind, financial economists across the world have long tried to point out the reasons for such stock market crashes. Most of their researches have focused on how effectively different models can explain the changes in the financial market with expectation that a proper diagnosis may led to proper treatment. Fore example, the equilibrium models of financial markets based on general equilibrium, such as the Capital Asset Pricing Model (W. F. Sharpe, 1964; J. Lintner, 1965) and the Arbitrage Pricing Theory (S. Ross, 1976), and the efficient market hypothesis have dominated the finance 
literature (E. Fama, 1970; J. Y. Campbell et. al. 1997) in an effort to properly price the securities and understand if there is any alpha. But market crash in every part of the world is a testimony of the failure of these theories in their abilities to predict both the equilibrium price of securities and the market conditions. Unpredictable behavior of stock markets, especially unexpected crashes, has been a nightmare for the financial world ever since capital markets came into existence; J. Barunik et al. (2009), Gadi Barlevya et al. (2003). D. Sornette (2003) described the overall Stock market and investment in stock market as clearly the big game in town. R. J. Limmack, C. W. R. Ward (1990) in their study raises interesting questions both regarding the usefulness of finance models in explaining and predicting share price behavior and also in revealing factors which led to the severity of share price movements in the crash period. Similar voice has been raised by Ilkka Virtanen et al. (1987) and S. J. Chang (1990) etc.

Moreover, various financial and mathematical models have also been used to explain the behavior of financial markets across the world. These include the use of cusp catastrophe model by Zeeman (1974), Thom (1975), Balasko (1978), Ho and Saunders (1980) and Jammemegg et al. (1986). J. Zeira (1999) using the events of boom and crash of 1929 and 1987 for a study with the idea of 'informational overshooting' explains booms and crashes of the market by arguing that if market fundamentals changes for an unknown period of time, prices experience a boom, which eventually ends in a crash, due to informational dynamics. D. Sornette (2002) in his famous study on 'critical market crash' has pointed that the stock market crash of 1987 was due to computer trading, derivative securities, illiquidity, overvaluation and others like the auction system itself, the presence or absence of limits on price movements, margin requirements, off-market and off-hours trading (continuous auction and automated quotations), the presence or absence of floor brokers who conduct trades but are not permitted to invest on their own account, the extent of trading in the cash market versus the forward market are the other reasons for the crash. It seems the whole market structure and its mechanism is the heart of the problem.

Some has blamed institutional investors for the crash and boom of the market including Barber and Odean (2003), Cohen et al. (2002) and Lakonishok et al., (1992). Martin T. Bohl et al. (2006) has found robust empirical evidence that the increase of institutional ownership has changed the autocorrelation and volatility structure of aggregate stock returns. However the study failed to discover the impact of institutional investors on destabilizing stock prices. The role of derivatives product in the major financial crisis in the world has been studied extensively including Chance (1995), Adam Tickell (2000), Cronon's (1991), Parsons (1988), Chew (1996), Grossman (1988), and Eric Ghysels et al. (2005). Most of the studies concluded that that futures markets and trading by foreign investors played a key role during world wide stock market crash specially stock market turbulence in 1997. George G. Kaufman (2006) has argued that derivatives product enjoys special protection and it is a sources of major risk in stock market while Ludger Hentschel et al. (1997) argued that derivatives are the source of systemic risk in the market and they are the cause of widespread default risk in the market.

Finally, in an effort to establish financial market rationality several study including Balke et al. (2001); Carlson \& Sargent (1997); Heaton et al. (2000); Kopcke, (1997); McGrattan \& Prescott (2000) etc have tried to show relationship between fundamental variables like industrial production, corporate earnings or GDP and stock market performance with the data of U.S. as well as in other G-7 countries from the 1950s to the 1990s. Most of these studies have failed to document any clear relationship. Therefore, several authors including Binswanger (1999), Shiller, (2000) have argued irrational exuberance or speculative bubbles as the cause of the problem. Away from all these failed diagnoses and to say things straight the real reason is simple. $58 \%$ of the mortgaged housing property (based on which mortgage backed securities MBS is issued) had been purchased for speculation purpose. Moreover, with Credit default swap issued against MBS, without any regualtion by speculative hedge fund, the worsening situation has only exaggerated. Therefore, excess housing inventory at the hand of speculator has led housing price to decline when they have tried to sell to realize profit. This has led to decline in mortgage cash flow and investors like banks, pension funds, headge funds etc. have depleted their capital causing to banks failure; which eventually forced them to recover cash from investment in derivative securities, stocks and bonds etc. A huge sell pressure by these institutional investors in the financial market has led the global financial markets specially, stock exchanges, bond markets, banking \& insurance industries to fail. The fictitious nature of bubble growth is doomed to fail. This is a fact. Indeed the reality is that the size of global GDP in 2007 was only $\$ 54.34$ trillion, where as, the size of global stock markets was $\$ 52$ trillion, size of bond markets was $\$ 48$ trillion and size of global derivative markets was around $\$ 668$ trillion (Note 7).

Therefore these entire academic maneuvers have failed to see the real cause. Rather all have tried to work on surface to diagnose the problem and prescribe solutions. Thus we see the G-8 summit come up with their easy way to solve it i.e. regulation, as they see lack of regulation was the main problem. How digressed! Free market proponents have come up with regulations as solutions!! Indeed a number of regulations including Banking 
(Special Provisions) Act 2008, Housing and Economic Recovery Act of 2008, Economic Stimulus Act of 2008, Emergency Economic Stabilization Act of 2008, Troubled Assets Relief (TARP) Act, 2008 European Union stimulus plan, American Recovery and Reinvestment Act of 2009 etc (Note 8) have been enacted to solve the crisis. Other than regulations they have also tried to solve the problem by bringing liquidity to the market, with interest rate measures, by purchasing troubled assets, by nationalization and bailouts; Abid Mustofa (January 2008).

\section{Capitalism Holds Its Own Failures}

The current financial crisis was an inevitable something. If someone scrutinizes the events immediately after the eventful month of September 2008, G8 leaders meet together and have failed to reach an agreement regarding the causes of such crisis, let alone the solution! Latter on multiple of such summits also failed in vain in identifying the reasons. Indeed the prolonged deep down economic rescission in Europe and USA is a testimony of the failure of such high level meetings. On $20^{\text {th }}$ Dec, 2011 International Monetary Fund (IMF) chief's statement "the world economy is at a dangerous juncture" essentially speaks about reality of the prolonged crisis.

The failure of identifying the root causes has been pointed in the study of Adrian \& Atkinson (2009). Adrian \& Atkinson (2009) have suggested that the factors mentioned in the scholarly investigation above is in fact like focusing on symptoms of the crisis and distracting attention from the pivotal role of policy making in causing the crisis specifically creating distorted incentives and then permitting a massive expansion of leverage enabling the private sector to take full advantage of them.

Thus this article strictly highlights the reasons behind the crisis from an alternative i.e. Islamic perspective to bring more intellectual inputs to our understanding of the dimensions and nature of the crisis to aid fruitful policy decisions in future.

This section has been divided into two categories. Firstly, the philosophical reasons which includes (1) failure to identify the main economic problem, (2) treating individual as business units, and (3) creation of a virtual economy alongside the real economy. Secondly, the functional reasons which include (1) faulty formation of corporate structure, (2) wrong definition of property ownership (3) complex financial products and practices, (4) interest based economy, and (5) currency standard.

\subsection{Philosophical Reasons behind the Crisis}

From a philosophical point of view, the capitalist economy has failed to define the real economic problem of a society. Western philosopher and academicians defined 'scarcity' as the core problem of economics, even saying scarcity is a curse. Limited resources and unlimited demand is a dilemma and constitute the major economic problem. Moreover it argues that only the invisible hands of market mechanism i.e. demand and supply has the magical power to decide best whose needs will be fulfilled; Robbins (1932), P.A. Samuelson (1969), Rüdiger Dornbusch (1990) etc. This understanding is synonymous to a natural inability to recognize the truth that, the creator of the world Almighty has provided humanity with enough bounty to live happily and fulfill their basic needs. The only problem is the problem management. Therefore, question to be asked is how true this basic "scarcity" philosophy of capitalism is?

Robert David (2006) argued that if someone wants to play casino and he (she) has the means to pay for it, it is an effective demand and it will be fulfilled by channeling nation's economic resources to produce casino. If anyone wants to see fornication and he (she) can pay for it, resources will be committed to produce fornicated movies even if many people in the country is crying for basic needs. So the movie of 'Basic Instinct' has been produced with the opportunity cost of depriving thousands basic rights. In 2003 the global fashion industry was worth $\$ 2.5$ trillion (greater than the global weapons industry!) and according to Top Ten REVIEWS Releases in 2004, total revenue of porn industry was $\$ 57$ billion (Note 9). Interestingly this amount is higher than the year 2008 GDP of around 138 countries of the world (note 10). Moreover according to World Bank (2002) more than \$1 trillion US dollars is paid in bribes each year while size of world economy at that time of just over US\$30 trillion. This is exactly the same amount spent to fight poverty around the globe since the end of World War II up to year 2002 (Note 11). Imagine the cost of two US wars after 9/11 has been around \$1.32 trillion up to 9th April 2012(7.30 PM Bangladesh standard time) (Note 12) which is more than the GDP of 180 countries of the world. So, according to the philosophy of scarcity the world has the problem of poverty because the world produces a total of 2.3 billion tonnes of food while the world demand is only 1.3 billion?

Moreover, ever since capitalism gained momentum with utopian (Note 13) concepts like freedom of various types, humankind has lost its way. In capitalist economy, it has been taught that, economics does not deal with morality; George Reisman (1996), Ayn Rand (1964), Bernard Siegan (1980), Ludwig von Mises (1966), J. M. 
Keynes (1936). Therefore, capitalist economy from its ideological viewpoint treats individual as an economic unit who's every biological, spiritual and survival instinct can be an object of business. Lust for profit is the ultimate goal, Leonard Peikoff (1989). Human love, emotions, basic needs like foods, clothing and shelter etc. are issues of business. So, they sell insurance policy, by saying that, what will happen to your family or kids if you die? Take our life insurance policy! So on and so forth. Therefore, in current crisis we have seen that, human basic rights like housing has became a product for sub-prime mortgage banks that started the problem. Thus there is a growing trend today, according to Heidi N. Moore (2008), in Europe, particularly in France and Germany that they are teaching their children a "philosophy of failure" based on the idea that capitalism is immoral, savage and unhealthy and only $36 \%$ people endorse the capitalist idea of free enterprise system.

Finally from a philosophical angle, current financial crisis has been due to creation of twofold economy under capitalist economic framework i.e. financial economy and real economy; M. Malkawi (2008). In real economy things that can be directly consumed or used for further production. Whereas, in financial economy, claims on real assets i.e. financial assets (e.g. shares, bond etc.) are traded with price determined by their demand and supply. Moreover, western financial economists, institutions claim that, demand and supply of financial assets are based on information regarding the future prospects i.e. the real assets produced at real economy. However, in reality capitalism has failed to show any conclusive example of strong form of efficient financial market over its entire reign in power as argued by Mathias Binswanger (2000), Jeong-Ryeol Kim (2003), Ali F. et al. (1986) etc. Moreover the USA had GDP of $\$ 13$ trillion in 2007, but its financial markets had market capitalization much higher than its GDP. Similarly the size of global GDP in 2007 was only $\$ 54.34$ trillion, where as, the size of global stock markets was $\$ 52$ trillion, size of bond markets was $\$ 48$ trillion and size of global derivative markets was around $\$ 668$ trillion (Note 14). It means if the world is sold about 13 times to Mars or Jupiter, still the world will be unable to repay its debt! Similarly, it requires USA to be resold for more than 30 times to other countries to repay its entire obligation! What an economy that calls for greed and growth! This form of growth measure is neither beneficial nor tangible and it is a toxic growth based on debt; A. Khan (2008). The German Minister of Finance Peer Steinbrueck launched an attack on the capitalists in the country, saying, "The biggest threat to the system of social market economy comes from the greed of senior enterprise managers...selfishness, the lack of cooperation, and lack of empathy towards others amongst the German elite has affected the emotions of the middle class in society and made her lose faith in the presence of social justice." (Al-Jazeera, 19/11/2008). The current financial crisis has proved that, western financial system neither has its moral sense nor has its measures to deal with problems as also advocated by France Prime Minister, Francois Fillon who said 'the world is on the brink of the abyss.' (BBC, 04/10/2008). Angela Merkel, the Prime Minister of Germany, said, 'the era of the domination of the economy and one currency has gone forever.' (Al-Arabiyyah, 04/10/2008). Those who still back this financial system let for them that, 'western financial system neither has its moral sense nor has its measures and wait till such catastrophe befalls upon humanity". Therefore the issue of "scarcity" is a legitimate question and it must be understood that we need an economic model that develops "natural equilibrium" in pursuing growth and prosperity. Because once the idea of scarcity is adapted as the core economic problem and effective demand is allowed to determine the resources allocation presuming that it will lead to profit, there will always be an incentive for unhealthy competition. The numerous examples of moral hazard in financial service industries are perfect evidences which also have been documented as the root cause of current global financial crisis. Therefore attainment of "natural equilibrium" which is viewed as a dynamic process of applying the idea of inner restraint of human to ensure fulfillment of the need of the society and adjustment of long term economic wellbeing is a panacea from financial crisis.

\subsection{Functional Reasons behind the Crisis}

Given the philosophical setup, this section presents the functional reasons those can be termed as the catalyst to aggravate the crisis.

\subsubsection{The Fallacious Corporate Structure}

In the capitalist economic model an erroneous corporate structure is required to aid the achievement of its fundamental philosophy of greed. According to Hicks, A et al. (2008) in the west a company is created as an artificial being under the prescription of law. The promoters generally lay down this constitution and thus it seeks to achieve their goals along with their appointed management; Sanjai B. et al. (2007); Ujo Goto et al. (2001). The trading of stocks takes place in the financial markets with no formal acquaintance between the buyers \& sellers. Thus for the broker (Note 15), who is also a profit maker, manipulations of stock prices become the order of the day. Thus by allowing buying and selling of corporate ownership interest without a formal offer in the name of promoting liquidity, this system in fact it creates speculation as evident by Thomas Lux (Jan 1998), D. Sornette (2000), Allen C. Goodman et al. (2008) etc. Again, since the investor is not obliged to hold the stock, 
they try to capitalize on speculative gains which result in volatility of the stock markets. Furthermore, these companies were created with a limited liability mandate (Note 16); so, even if Lehman Brothers has defaulted with $\$ 44$ billion debt, the debt holders could actually realize maximum $\$ 2.7 \mathrm{bn}$ ! What a corporate system! Therefore, this corporate structure naturally allows the firm to take any level of risk only to ensure profit maximization, because its ultimate level of maximum debt burden is limited by its share capital and it ensure concentration of fund by the wealthy capitalist while the law allows them to reject claim of the creditors above certain level in case of bankruptcy. Just imagine if limited companies enjoy the limited liability benefits why the same is not allowed for sole proprietorship?

Islam fundamentally views this corporate structure as invalid one and it does not recognize the trading of the ownership or debt via issue of securities. This is due to a number of aspects including:

1) Fundamentally this type of contract contradicts the Islamic rules of contracts. Because in this system ownership could be exchanged very quickly without the need for two people to sit down and have an acquaintance for formal offer and acceptance. However a counter argument for that is this process will create illiquidity in the market. The fact of the matter is under current system, secondary market which allows almost unrestricted trading of ownership certificates or even debt certificates in the mane of promoting liquidity in fact have become a source of illiquidity in the recent times, creating credit crunch. Moreover, a legitimate question is whether liquidity is more desirable public goods and economic stability? Why these people who buys and sell continuously do even bother to come to market when they have not shown honest intension even to invest in corporations rather than profiting from an intentionally created volatile market? Moreover due to the ill design of the current system of ownership transferring process of corporations Malcolm Glazier for example take a bid to buy Manchester United FC and he imposed his will on the company (i.e. he brought shares) even though other shareholders were against such an action. It was a valid form of acquiring ownership from a legalistic angle of capitalism even though there was only one person in the contract (acceptance but no offer). This is unlawful in Islam. The Holy Quran Says "And take witnesses when you trade" [TMQ] and "Except if it is trade of mutual agreement among you" [TMQ]. Narrated by Ahmad and Ibn Majah in the authentic sayings of the messenger of Allah (pbuh) said: "Verily trade is only upon mutual consent". Narrated from Yaheya ibn Yaheya, Yaheya ibn Aiyub, Kutaiba and Ibn Omor that prophet (pbuh) said 'the trade between buyer and seller is not finalized until they leave one another. However, if the condition of kheyar (Note 17) is an applied (muslim)'. Moreover, when people trade they must not sell it before the goods come to their physical possession.

2) Moreover, in Islam all limited liability companies are null and void and different company structures according to shari'ah are permissible because of the sayings of prophet (pbuh). Al-Bukhari reported on the authority of Abu Hurayrah that the messenger of Allah (pbuh) said: "He who takes money from people with the intention of paying it back Allah will pay on his behalf, and he who takes it with the intention to waste it Allah will waste him." Ahmed also reported on the authority of Abu Hurayrah who said: The Messenger of Allah (pbuh) said: "You shall return the rights to their rightful owners on the Day of Judgment, even the ewe with no horns will get even with the ewe with horns by butting it back." It is because of this principle there is no permission of limited liability companies in Islam. Thus in Islam unrestricted trading of debt is incapacitated, which naturally reduces abrupt growth of corporate profits as well as abrupt fall of corporate into bankruptcy. In the recent financial crisis it has been found that the limited liability provision has helped and aggravated the number of bankruptcy because under current system of there are situation when there is an incentive for bankruptcy as well, as manifested in the example of Lehman Brothers.

\subsubsection{The Complex Financial Products, System and Practices}

Until the 1960's the developed world was largely engaged in manufacturing, with most of the labor force employed in real industry. However, over the last 30 years growth focus have shifted from industry to services to the point that service sector now represents over $80 \%$ of the US economy with the financial sector being the largest one; Adnan Khan (2008). The start of stock market activities as the heart of financial sector at the beginning of 20th century crated a new phenomenon; Ayn Rand (1964), which is known as virtual economy; M. Malkawi (2008). This has helped the wealthy capitalist to increase their fortune at a much higher rate than it is possible in real economy; W. Max Corden (2008). The practice has become so sophisticated that various products have been created which allow an investment in a paper with no real asset represented. Robert Ingraham (2007) puts it in this way 'this is simply gambling'. For example when the stock price of 'Jumuna Oil Ltd.' grew from offer price of BDT. 10 to BDT. 780 on the first day of trading at Dhaka Stock Exchange (DSE) in Bangladesh, is it that the company actually increased its real assets (i.e. production of oil) by 78 times in one day? No!! Similarly the increase in the price index financial market during the preceding periods for example from 1925 to 1929 by $120 \%$ in USA, was absolutely without any justification since the productivity in the real economy for the same 
period did not exceed $17 \%$ (Note 18).

Therfore, Nicolas Sarkozy lambasted USA financial system as 'the American madness' and said, "laissez-faire" economics, "self-regulation" and the view that "the all-powerful market" always knows best are finished (Note 19). Indeed this is madness. Russian Prime Minister V. Putin commented that "Everything happening now in the economic and financial sphere began in the United States. This is not the irresponsibility of specific individuals but the irresponsibility of the system that claims leadership (Note 20).' The following discussion examines a few of such products in assessing their contribution to foster the financial crisis.

\subsubsection{Short Sales}

By allowing the practice of short sales, during the time of declining value of stocks, a broker, who holds inventory of stocks of the investors, may sell the investor's shares at higher price and when the market falls further due to immense sell pressure, the broker buys back the stocks at lower price to give it back to the investors. So naturally, the broker will try to increase sell pressure to gain more which may even result in market crash. Diether, K. et al. (2009) showed that short selling accounted for $24 \%$ of New York Stock Exchange and $31 \%$ of NASDAQ volume prior to the financial market crash of 2007. Islam has forbidden such trading. An ahadith (i.e. sayings of prophet pbuh) narrated from Hakeem bin Hazam who said: "I said: O Messenger of Allah, there comes to me a man asking me to sell what I do not have, then I buy if from the market. He said: Do not sell what you do not have" (narrated by Ahmad). Another ahadith form Amru bin Shuaib from his father from his grandfather who said: The messenger of Allah (pbuh) said: "It is not allowed to borrow and sell, nor two conditions in one sale, nor a profit that is not included nor the sale of what you do not have" (narrated by Abu Dawud). Moreover Islam does not allow something to be sold before it has been owned and possessed. Abu Dawud narrated "that the prophet (pbuh) prohibited that goods be sold where they are bought until the trader collects them to their mounts" and due to what was narrated when the prophet (pbuh) sent Uttab bin Usayd to Makkah, he said: "prohibit them from buying that which they have not taken possession of." These ahadith are explicit in prohibition of the practice of short sales. According to Robert Battalio et al (2011) of late some of the contemporary economic policy measures have been trying to ban or limit short-sales for example on August 11, 2011, European regulators, in response to the continent's debt problems, decided to limit short selling, while Greece and Turkey were supplemented by bans on short selling of financial stocks in France, Belgium, Italy and Spain. On August 25, 2011, Italian and Spanish regulators extended their bans through September 30, 2011 while French regulators indicated that their ban could last until November, 2011. Even though Beber and Pagano (2011) tried to show that short selling ban "at best neutral in its effects on stock prices", the study result was not conclusive due to its failure to account the legislative environment and maturity of the market of the two groups of countries where short sales were ban and short sales were not ban.

\subsubsection{Gambling and Hyping}

Someone renowned likes George Soros of Quantum was the direct beneficiery of 1997 the Southesat Aisan financial crisis and Indeed he was accused by the Malaysian Prime Minister of causing the collapse in the Asian financial system in 1997 by his monetary machinations during a financial crisis. He is considered an "economic war criminal" in Thailand. In 2006, he was convicted in France of illegal insider trading in his attempt to take over the Societe Generale Bank, and paid a fine of $\$ 2.9$ million, mere chicken feed considering that his income that year was $\$ 3$ billion (Note 21). Islam has clearly made such gambling and hyping i.e. lying in case of trade unlawful. The Holy Qur'an says in Chapter 03 verse 90-91 clearly states that ' $O$ you who believe! Verily khamr (alcohol/intoxicants) and gambling and idols and divining arrows are only an infamy of Satan's handiwork. Leave them aside in order that you may succeed. Satan seeks only to cast among you enmity and hatred by means of alcohol and games of chance, and to turn you away from remembrance of Allah and from the prayer. Will you then stop (doing that)?'Under current market mechanism of instantaneous inability to prove a link between real and financial economic outcome and with ambiguous performance of leading and lagging indicators, gambling and hyping has become the order of the day behind every single financial market meltdown even though in most times these master minder remains out of touch because of their implicit relationship with the system itself; Ibrahim Khalid Report (2011) (Note 22).

\subsubsection{Margin Trading}

This is a technique where the bank provides loan to brokers who eventually provides it to wealthy investors to buy shares at margin. So, during bullish market condition, wealthy investors can use margin facilities to buy more shares and thus can magnify his gain. But when the share price falls, the margin investors sells shares to maintiain the margin which increases sell pressure and decreases price drastically - resulting market to crash and individual investors without margin investment suffering the most. This has been cited as a factor contributing to 
the Stock Market Crash of 1929. Islam has disallowed his types of trading since it celarly involves the presense of interest. Quran says "Those who devour (take) interest (riba) cannot stand except as the one whom the Satan, by (his) touch, drives him to madness. That is because they say: Trade is just like riba, whereas Allah permitted trade and forbade riba. The one to whom an admonition from his Lord comes and he refrains (in obedience thereto), he shall keep (the profits of) that which is past, and his affair (henceforth) is with Allah. As for him who returns (to usury), such are rightful owners of the fire. They will abide therein eternally." [Al-Baqarah: 275]. Moreover Abu Huyayra who said: "The Messenger of Allah (SAW) prohibited the sale of (husat (Note 23)) and the sale of risk (gharar)."

\subsubsection{Financial Derivatives}

This is one of the most unrealistic type of products, that shows how seduced the westen economy is about profit. It is related with different form of future transactions. Indeed derivatives like exotic products have been blamed for all the marjor financial markets crash. Still they are almost always traded with the OTC derivative market as the largest market for derivatives remains unregulated. For example after initiation in 1997, Credit Default Swaps became legal, and illegal to regulate, with the Commodity Futures Modernization Act of 2000 (Note 24), which contains 11,000 pages and it took only less than a week to pass by congress and signed by then President Clinton. From then on derivatives products have grown unrestrictedly without any sign of reducing. According to the Bank for International Settlements (BIS Dec, 2007) the total outstanding notional amount is $\$ 548$ trillion in listed credit derivatives and $\$ 596$ in notinal OTC derivatives, whereas only 10 years ago, the total derivative contracts had a notional value of $\$ 62$ trillion. Of this total amount, $66 \%$ are interest rate contracts, $10 \%$ are credit default swaps (CDS), and $9 \%$ are foreign exchange contracts (Note 25). According to Newsweek magazine the size is even bigger amounting around $\$ 668$ trillion (Note 26). What a spectacular growth of virtual economy! These contracts are speculation and gambling. Wareen Buffet (2002) viewed them as time bombs, both for the parties that deal in them and the economic system. However, today it designated as "weapon of mass financial destruction (Note 27)." Though Davies (2008) and Stiglitz (2009) pointed that derivatives did not caused the initial financial meltdown, however it has certainly accelerated it once the subprime mortgage market collapsed.

A closer scrutiny of this financial artifact suggests that one of the parties has a definite interest in a bad economic outcome to take place in the prefixed future date. Thus tampering of the market trends or the variables those moves and shakes the market becomes a custom. For example in CDS investors to speculate on changes in an entity's credit quality and CDS spreads will increase as credit-worthiness declines. Thus clearly someone has definite interest in the default of the entity. Imagine if the world's GDP is only $\$ 54$ trillion, why there should be $\$ 668$ trillion notional value of derivative securities market? And if this is the case why should we have a stable global economy? Therefore Islam has clearly prohibited such transaction because of interest, gambling and the ill intension that such contract may result on the part of those who enter into such contract. Ahmad narrated "the Prophet (pbuh) prohibited two contracts (safqah) in one contract. Abu Dawud narrated that the Messenger (pbuh) said: "Whoever sells two sales in a sale, for him is the lesser (awkis) of the two or (it is) riba" If one of the contractors said to the other, 'I sold you my house for one thousand upon your selling me your house for one thousand' and he says, 'I have accepted' in this one sale contract there occurred two sales which is not permitted since the Prophet (pbuh) prohibited two sales in a sale and two agreements in one agreement.

\subsection{Interest Based Banking System}

Another fundamental reason behind the financial market crash was the unfortunate presence of usurious banking system. The most common arguments for these banks includes formulation of capital, safe investnemnt leading to job creation, aid to production \& economic growth etc.; Robbins (1932). How realistics are these claims?

Firstly, where are Lehman Brothers, Citi Goup's, AIG's, USB, Merril Lynch, HSBC's credentials of safety investment in terms of investment in around $\$ 664$ trillion derivative markets, while they knew the world GDP is only $\$ 54$ trillion along with historical realties of bankig default? Morever, if $80 \%$ of total global investment goes to financial and service industry, while $20 \%$ goes to real economy, how safe are these investments? Since there imbalance between the financial and real economy make the financial service industry is unsustainable.

Secondly, the argument regarding banks ability in creating economic efficiency by decreasing information asymmetry is a mere rhetoric. For example if NatWest Bank offers loan at $6 \%$ while HSBC offers at $4 \%$, surely any company will finance from HSBC bank as it will reduce the firm's financing cost which invariably will reduce cost of doing business since it become cost effective. If this is ture, what if a model of financial system providing loan at zero percent! Morevoer, today the banks must invest their deposits in high risky projects to ensure the payment of promised interest to the depositors and earn their expected profit as banks has to keep liquidity reserve in the form of SLR and CLR of around 10-15\% of the bank's deposit. Moreover, there is a 
minimum deposit reserve in every account of a bank. Therefore, the existing system fails to utilize the full amount of national savings in the name of preserving liquidity which increases financing cost for the borrower resulting higher production cost. Moreover, banks are allowed to create M2 along with credit creation process, which results in a bubbled economy as a huge money supply is generated by the banks whereas the real economy falls short that. For example in USA it is legal to give $\$ 30$ aginst $\$ 1$ deposits through credit creation process!

Finally, banks top management understands that, their bonus and perks are related with banks profitablity. So they force the part-time or trainee officers with targets to sell loan as well as collect deposits. Because higher the loan sales, bigger will be the bouns. This has lead to devastated nature of leding with creation of different credit and derivative products as unearthed after the fallout of global financial crisis. For example we see in December 2006 interest rate swaps was $\$ 229.8$ trillion in OTC market whereas the global trade was only $\$ 26$ trillion, without any economic justification.

Islam has clearly forbidden any transaction based on inerst. Quran in Chapter 2 and in verse no. 275, 277-278 clearly states that, "those who devour (take) interest (riba) cannot stand except as the one whom the Satan, by (his) touch, drives him to madness. That is because they say: Trade is just like riba, whereas Allah permitted trade and forbade riba. The one to whom an admonition from his Lord comes and he refrains (in obedience thereto), he shall keep (the profits of) that which is past, and his affair (henceforth) is with Allah. As for him who returns (to usury), such are rightful owners of the fire. They will abide therein eternally.... y ye who believe! Observe your duty to Allah, and give up what remained (due to you) from usury, if ye are (in truth) believers. And if ye do not, then be warned of war (against you) from Allah and His messenger."

\subsection{Abandonment of Gold Standard}

Finally, another most important reason behind current financial crisis was the introduction of paper based fiat currency with no full backing of real commodility i.e. gold or silver. Upon the establishment of Bretton Woods and subsequently in the 1970s with establishment of paper standard gold standard was abandoned. Upon the establishment of paper standard mostly based on dollar, most countries in the world is using US\$ dollar as reserve currency against the issue of local currency in the domestic economy. The simplest meaning of dollar reserve system is that, if for example central bank of country " $\mathrm{X}$ " following dollar standard goes to US Federal Reserve and claims real assets against the dollar reserve it has, US central bank is legally obliged to pay real assets against the value of the reserve. However, it is of no surprise that for Federal Reserve issue of dollar is not fully backed by any real assets (except a very insignificant percentage) rather than the confidence of US government. So what country " $X$ " can end up is simply receiving US government confidence or more promise in the form of "US government certificates". In the same breadth theoretically imagine if China asks USA to repay with any real assets against around \$1.6 trillion dollar reserve China holds, USA won't be able to pay! Because USA does not have any real assets against such dollar! Indeed issue of dollar by USA is a big business as www.wiki.answers.com reports that, according to Bureau of Engraving and printing it costs only 6.2 cent to print any denomination of dollar currency by USA. Imagine Bangladesh receives U\$100 note with its hard earned export revenue or remittance, while for USA it is just a matter of printing a $\$ 100$ bill with a cost of 6.2 cents only. From 1970s onward the average growth of US economy was around 3-4\%, whereas the printing of dollar has increased each year by $12-14 \%$ (Note 28). What a good business it is for USA! This has created inflation around the world and also allowed USA premier ability to consume goods from around world by geometrically increasing its purchasing power and it has been pretty successful in doing so if someone considers the US trade deficit which is $57.40 \%$ of entire worlds' trade deficits. Most of these were due to US ability to print money almost without any restrictions. However, today this has becomes one of the most important macroeconomic nightmare for USA which systematically crippling the global economy. Moreover, the effect of removing gold standard has resulted continuously increasing inflation around the world. For example prior to 1971, dollar was freely exchangeable for gold at the fixed rate of $\$ 35$ per ounce, but when standard was removed to issue dollar it became freely floating and today it takes around $\$ 1600$ per ounce of gold (Note 29). Statistics tells us that the total amount of gold that has ever been mined has been estimated at around 158,000 tons. Assuming a gold price of $\$ 1,600$ per ounce, the total value of all the gold ever mined would be around $\$ 7.2$ trillion. This is less than the value of circulating money in the US alone, where around \$1.4 trillion is in circulation and another $\$ 11$ trillion through banking deposits. However, the real problem is not that there is too little gold but the fact that there are too many dollars (Table 2). How much dollars can purchase (purchasing power) is the real issue for people around the world, because the US continues to freely print the dollar, and each time it does so the dollar purchases less (devalues). The US who has the dollar as its national currency, can continually print money to meet its economic needs as evident by the printing of additional US\$700 million in the initial phase of the series of bailout package. For the rest of the world because international financial markets and global commodities markets are all priced in dollars 
they would need to exchange their domestic currency for dollars and hope it retains its purchasing power. If it doesn't then they will need to give up more of their domestic currency to buy dollars.

Table 2. World fiat money (CIA Fact book 2011)

\begin{tabular}{lc}
\hline Narrow money & $\$ 22$ trillion \\
Broad money & 75 \\
Domestic credit & 105 \\
External debt & 60 \\
Foreign exchange reserve & 10 \\
World fiat money base & 272 \\
Word GDP & $\$ 50$ trillion \\
Ratio of Fiat money to GDP & $5.4: 1$ \\
\hline
\end{tabular}

Joseph T. Salerno (1982) thus argued the world should embark in a system where 'government should totally and permanently be debarred from manipulating the supply of money'. Mises (1978) 'that the gold standard alone makes determination of the monetary unit's purchasing power independent of the ambitions and activities of dictators, political parties and pressure groups'. For example in the first round of the global financial crisis, US government has taken a $\$ 700$ million package, mostly by printing additional fiat currency to solve the problem of credit crunch. This was only possible due to absolute monopoly of the government to print more dollar bills which subsequently created more problems in the economy i.e. inflation. F. A. Hayek (1978) argued that, no authority can beforehand ascertain, and only the market can discover, the 'optimal quantity of money.' The action of the US government of printing additional cash to fight credit crunch also confirms that, in a time when decisive actions are required, under fiat system government completely fails in determining the 'optimum' level of money supply required in the economy. Moreover in modern democracies there is no reason to believe that government will circulate the optimum amount of government-monopolized paper fiat money, since there will always be the case of printing 'cheap money' to win votes. That is why Salerno (1982) argued that it is surely not unreasonable to characterize governments as inherently inflationary institutions.

As a comparison the purchasing power of gold and silver has remained extremely stable over not just the past century, but over most of history. The price of 100 barrels of oil measured in ounces of gold has remained fairly stable between 5 and 10 ounces of gold for the last 100 years. From just 1973 to 2008, the price of a barrel of oil in US Dollars increased by $3500 \%$. Over the same period the number of ounces of gold required to buy 100 barrels of oil rose by only $18 \%$ !!

Recently World Bank president Robert Zoellick, Warren Buffett's father Howard, Jim Grant, and, most recently, Kansas Fed president Thomas Hoenig, all voiced their support for a return to a gold standard. Alan Greenspan said (2007) "We have at this particular stage a Fiat money which is essentially money printed by a government and it's usually a central bank which is authorized to do so. Some mechanism has got to be in place that restricts the amount of money which is produced, either a gold standard or a currency board, because unless you do that all of history suggests that inflation will take hold with a very deleterious effects on economic activity...There are numbers of us, myself included, who strongly believe that we did very well in the 1870 to 1914 period with an international gold standard (Note 30)."

Islam has completely annulled paper currency standard with fractional reserve system. In fact Islam has always argued for a stable economic system thus Islamic currency system is based on real assets i.e. gold and silver. Prophet (pbuh) has argued this number of times in his sayings as reported by At-Tirmidhi, Muslim and other authentic books based on prophet (pbuh) sayings.

Finally Jicklin (2010) in Congressional Research Service (CRS) report identified 26 major reasons behind the global financial crisis i.e. imprudent Mortgage Lending, housing bubbles, global trade imbalances, securitization, lack of transparency and accountability in mortgage finance, rating agencies, mark-to-market accounting, deregulatory legislation, shadow banking system, non-bank runs, off-balance sheet finance, government mandated subprime lending, failure of risk management system, financial innovation, complexity of financial instruments, human frailty, bad computer models, excessive leverage, relaxed regulation of leverage, credit default swaps (CDS), over-the-counter derivatives, fragmented regulations, no systematic risk regulator, short 
term incentives, tail risk and black swan theory. It seems that the entire capitalist financial system holds its own failure!!

\section{Islamic Solution and Conclusion}

From the earlier discussion it is clear that Islamic approach of organizing mans various needs including the economic one is different from the existing system and it does not recognize a virtual financial system that is alien from the real economy. This includes existing form of usurious banking system, financial markets with unrestricted exchange of ownership, dollar currency standard, and current form of corporate structures etc.

In Islam the highest priority of economic system is people and their needs irrespective of their creeds and the whole system is built on this fundamental principle. Prophet (pbuh) said that: "The son of Adam (i.e. the entire humanity) has no better right than that he would have a house wherein he may live and a piece of cloth whereby he may hide his nakedness and a piece of bread and some water" (Tirmidhi). Islam focuses on the needs of the people which the ahadith (i.e. sayings of prophet pbuh) has outlined, not on increasing Gross Domestic Product (GDP), which is a fallacious measure of economic wellbeing.

Islam views the resources to be ample enough to completely satisfy the basic needs of all humankind and Islam has facilitated the acquisition of livelihood including goods and services Islam via lawful means and strictly prohibited the acquisition and disposal of livelihood in some unlawful means. It certainly did not make 'freedom of ownership' the basis of the economic system or even the socialist principle of 'from each according to his ability, to each according to his needs'.

Islam defined the legal means and forms of ownership. Islam defined the valid contracts through which possession can take place restricting unlimited and speculative transfer or trading of ownership or debt. However, Islam leaves humanity free to develop the styles and means by which they can earn, as Islam did not interfere in the production of wealth. In Islamic economy, all participants focuses only on real economy and through employments, company profits, utilization of land (agriculture) and manufacturing; wealth is generated and circulated in real economy. This brings huge benefit of wealth only circulating in one sector - the real economy, where all can participate. So, with the closure of interest based baking system and gambling casino financial markets no one will have incentives to deposit money in bai'tual-mal (financial institution that will give people the deposit facilities for safety without any interest; moreover a percentage charge will be imposed upon each year). Thus the surplus household is left with three options: more consumption, lending to others for business or personal purpose, to invest in real economy to start their own or shared business by following any of the five types of company structure in Islam (Note 31) i.e. company of equal (al-inam), company of bodies (al-abdan), company of body and capital (mudhararaba), company of reputation or faces (al-wujooh), and company of negotiations (mufawadha). This will create an unprecedented number of real economy based entrepreneurs, production and consumption driven economy creating employment opportunities and circulation of wealth in productive real sectors. Moreover bai'tul-mall will support business growth with fund requirement in case of expansion and other needs by informing the depositors about the potential borrower allowing them to take the lending and borrowing decisions. This will completely reduce the credit risk of bai'tul-mal and the borrower will receive the fund once the lender is satisfied with the nature of business and its prospects as well as share of profit in a face-to-face negotiation. The lender will bear the entire risk in case of default. The fund will be disbursed at zero interest rate and for the lender this is a better option since deposit in bai'tul-mall will generate negative interest rate due to the annual charge. Surely trust will be a crucial factor in conducting business by the borrower and his entire aim will be to generate good return for his effort and for the negotiated profit of the lender. As prophet (pbuh) has said, "An honest and truthful businessman shall be in the shade of the throne of Allah". Moreover, Prophet (pbuh) said, Allah Almighty proclaims that, 'I am one third partner of a two man in partnership until one of them acts dishonestly to his partner, and in such event, I then leave them'.

Islam's monetary policy is centered on a legal tender based upon the Gold and Silver standard and not one based upon paper standard for interest rates to regulate inflation and the economy. When it comes to exchanging a commodity with a specific monetary unit, Islam has guided people to the monetary unit by which the exchange must take place. Unlike today Islamic system doesn't allow to print any amount of money and neither follows a fractional reserve system. Thus historically during the time of golden age of Islam from 1507 to1589, inflation rate increased only by $7 \%$ over eight decades. Moreover, Islam does not have a concept of income tax; value added tax, excise duties, nor national insurance contributions etc. Rather Islam puts the emphasis of taxation on wealth rather than income. This helps the citizen to reduce their financial burden and allows more equity in the distribution of nation's output.

Finally Islam has ordained the state to play a direct role in the economy and does not leave things completely to 
the market. Islam lays out three types of property: state, public and private. It designated any utility regarded as indispensable for the community, such that its absence would require people to search far and wide for it, as public property. It would then be publicly owned and the revenue generates would be administered for the benefit of all citizens. This is derived from the ahadith of the Prophet (pbuh) "Muslims are partners in three things: in water, pastures and fire." i.e. all instances of indispensable community utilities. Thus water sources, forests of firewood, pastures for livestock and the like are all public utilities as well as the mosques, state schools, hospitals, oil fields, electricity plants, motorways, rivers, seas, lakes, public canals, gulfs, straits, dams etc. Islam would allow ownership if it were not indispensable for the community. This solution will have a unique effect, as it will ensure all will receive the basic requirements to live and not be at the will of monopolies or high prices. Moreover Islam has strongly prohibited price fixing or creating monopoly, which will create a highly responsible market mechanism.

Moreover, Islam has a very strong and responsible mechanism to monitor the markets and financial dealings between (among) individuals with individuals, individuals with states, amongst states apparatus, states with states. The system of muhtasib or the judge of the markets monitors the markets for fair weights and measures and guards against cheating and deception in markets and public places in addition to monitoring other offences and violations as well. The judges rules in matters of all disputes including financial and economic which may emerge between people in their daily lives. Again with the administrative apparatus of the state is the mechanism to control the movement of money in the bai'tul-mall in its various categories like the zakat money, state money or the public sector revenues and monitors income and expenditure and ensures that money is placed in its rightful category. The judge court is the court of the unjust acts and takes complaints raised against the ruler if the citizens' rights are violated in any way, whether in matters of finance or economy. These monitoring or accountability apparatus ensures fairness in the economic system as required by the Islamic Shari'ah.

Therefore, under Islamic economic system a simple and tranquil world is possible to all people, Muslims and non- Muslims alike, so long as they live under the shade Islamic system. The failure of our economic models today and Islam's 1300 years long history of economic \& human prosperity is a simple reminder. The holy Quran says in chapter Al Mulk verse 14, "Should not He who has created know? And He is the most kind and courteous (to His slaves), the well-acquainted (with everything)."

\section{References}

Adam Tickell. (2000). Dangerous derivatives: controlling and creating risks in international money. Geoforum, 31(1), 87-99. http://dx.doi.org/10.1016/S0016-7185(99)00013-5

Adrian Blundell-W., \& Atkinson P. (2009). Origins of the financial crisis and requirements for reform. Journal of Asian Economics, 20, 536-548. http://dx.doi.org/10.1016/j.asieco.2009.07.009

Adnan Khan. (2008). Global Credit Crunch and the Crisis of Capitalism. London, P. 24.

Ahmed. M. (2008). The Birth of Global Economic Crisis. Working Paper 08, IBA, University of Dhaka.

Allen C. Goodman., \& Thomas G. T. (2008). Where are the speculative bubbles in US housing markets? Journal of Housing Economics, 17(2), 117-137. http://dx.doi.org/10.1016/j.jhe.2007.12.001

Ali F. Darrat., \& Tarun K. M. (1986). The behavior of the stock market in a developing economy. Economics Letters, 22(2-3), 273-278. http://dx.doi.org/10.1016/0165-1765(86)90246-6

Ayn Rand. (1964). Man's Rights: The Virtue of Selfishness (pp. 124-125). New York.

Barber, B. M., \& Odean, T. (2003). All that glitters: The effect of attention and news on the buying behavior of individual and institutional investors. Retrieved from http://ssrn.com/abstract=460660

Barunik, J., \& Vosvrda, M. (2009). Can a stochastic cusp catastrophe model explain stock market crashes? Journal of Economic Dynamics and Control, 33(2009), 1824-1836. http://dx.doi.org/10.1016/j.jedc.2009.04.004

Balasko, Y. (1978). The behavior of economic equilibrium: a catastrophe theory approach. Behavioral Science, 23, 375-382. http://dx.doi.org/10.1002/bs.3830230408

Balke, N., \& Wohar, M. (2001). Explaining Stock price movements: Is there a case for fundamentals? Federal Reserve Bank of Dallas Economic Review, QIII, 22-34.

Beber, A., \& Marco P. (2011). Short-selling bans around the world: Evidence from the 2007-2009 crisis. Journal of Finance. Forthcoming.

Binswanger, M. (1999). Stock markets, Speculative bubbles and Economic growth (1st ed.). Edward Elgar 
Publishers.

Cohen, R. B., Gompers, P. A., \& Vuolteenaho, T. (2002). Who underreacts to cash-flow news? Evidence from trading between individuals and institutions. Journal of Financial Economics, 66, 409-462. http://dx.doi.org/10.1016/S0304-405X(02)00229-5

Carlson, J. B., \& Sargent, K. H. (1997). The recent ascent of stock prices: Can it be explained by earnings growth or other fundamentals? Federal Reserve Bank of Cleveland Economic Review, 33(2), 2-12.

Chance, D. M. (1995). A chronology of derivatives. Derivatives Quarterly, 2(3), 1-8.

Chew, L. (1996). Managing derivative Risks: The uses and abuses of leverage. London: Wiley Publications.

Davies E. (2008). Creating more risk by trying to manage risk. Retrieved from www.blomerge.org

Diether, K., K. Lee., \& I. Werner. (2009). It's SHO Time! Short-sale price tests and market quality. Journal of Finance, 64, 37-73. http://dx.doi.org/10.1111/j.1540-6261.2008.01428.x

D. Sornette. (2002). Critical market crashes. Physics Reports, 378, 1-98. http://dx.doi.org/10.1016/S0370-1573(02)00634-8

E. Fama. (1970). Efficient capital markets: A review of theory and empirical work. Journal of Finance, 25, 383-417. http://dx.doi.org/10.2307/2325486

Eric G., \& Junghoon S. (2005). The Asian financial crisis: The role of derivative securities trading and foreign investors in Korea. Journal of International Money and Finance, 24(4), 607-630. http://dx.doi.org/10.1016/j.jimonfin.2005.03.002

F. A. Flayek. (1978). Denationalization of Money-The Argument Refined: An Analysis of the Theory and Practice of Concurrent Currencies (2nd ed.). London: Institute of Economic Affairs.

George R. (1996). Capitalism: A treatise on economics. Jameson Books, Illinois and Ottawa.

Gadi B., \& Pietro V. (2003). Rational panics and stock market crashes. Journal of Economic Theory, 110, 234-263. http://dx.doi.org/10.1016/S0022-0531(03)00039-5

Grossman, S. (1988). An analysis of the implications of stock and futures price volatility of program trading and dynamic hedging strategies. Journal of Business, 61, 275-298. http://dx.doi.org/10.1086/296433

George G. Kaufman. (2006). Derivatives and systemic risk: Netting, collateral, and closeout. Journal of Financial Stability, 2(1), 55-70. http://dx.doi.org/10.1016/j.jfs.2005.05.001

Hicks A., \& Goo, S. H. (2008). Cases and materials on company law. London: Oxford University Press.

Heidi N. Moore. (2008). Is capitalism immoral? Retrieved from http://blogs.wsj.com/deals/2008/02/29/is-capitalism-immoral/.

Ho T., \& Saunders, A. (1980). A catastrophe model of bank failure. Journal of Finance, 35, 1189-1207.

Heaton, J., \& Lucas, D. (2000). Stock prices and fundamentals. In B. S. Bernanke \& J. Rotemberg (Eds.), NBER Macroeconomic Annual 1999 (pp. 213-263). Cambridge, MA: MIT Press for National Bureau of Economic Research.

Ilkka V., \& Paavo Yli-Olli. (1987). Forecasting stock market prices in a thin security market. Omega, 15(2), 145-155. http://dx.doi.org/10.1016/0305-0483(87)90029-6

Jeong-Ryeol Kim. (2003). The stock return-inflation puzzle and the asymmetric causality in stock returns, inflation and real activity. Economics Letters, 150 -160. http://dx.doi.org/10.1016/S0165-1765(03)00059-4

J. M. Keynes. (1936). The general theory of employment, interest, and money. New York: Harcourt, Brace.

Joseph Z. (1999). Informational overshooting, booms, and crashes. Journal of Monetary Economics, 43, $237-257$. http://dx.doi.org/10.1016/S0304-3932(98)00042-7

Jammemegg, W., \& Fischer, E. O. (1986). Economic applications and statistical analysis of the cusp catastrophe model. Zeitschrift Operations Research, 30, 45-58. http://dx.doi.org/10.1007/BF01919499

J. Lintner. (1965). The valuation of risk assets and the selection of risky investments in stock portfolio and capital budgets. Review of Economic Statistics, 47, 13-37. http://dx.doi.org/10.2307/1924119

J. Y. Campbell., A. W. Lo., \& A. C. MacKinlay. (1997). The econometrics of financial markets (1st ed.). Princeton, NJ: Princeton University Press. 
Jicklin M. (2010). Causes of the financial crisis. A congressional research service report for congress, Prepared for Members and Committees of Congress. Retrieved from http://www.fas.org/sgp/crs/misc/R40173.pdf.

Joseph T. Salerno. (1982). Gold standards: True and false. The CATO Journal: An Interdisciplinary Journal of Public Policy Analysis, 3(1), 271-275.

Ludwig von M. (1966). Human Action (3d ed.). Chicago: Henry Regnery Co.

Leonard P. (1989). Fact and value. The Intellectual Activist, 5(1).

Lakonishok, J., Shleifer, A., \& Vishny, R. W. (1992). The impact of institutional trading on stock prices. Journal of Financial Economics, 32, 23-43. http://dx.doi.org/10.1016/0304-405X(92)90023-Q

Ludger H., \& Clifford W. Smith Jr. (1997). Derivatives regulation: Implications for central banks. Journal of Monetary Economics, 40(2), 305-346. http://dx.doi.org/10.1016/S0304-3932(97)00045-7

Mathias Binswanger. (2000). Stock market booms and real economic activity: Is this time different? International Review of Economics \& Finance, 9(4), 387-415. http://dx.doi.org/10.1016/S1059-0560(99)00056-8

McGrattan, E. R., \& Prescott, E. C., (2000). Is the stock market overvalued? Federal Reserve Bank of Minneapolis Quarterly Review, 2, 20-40.

Mises. (1978). On the Manipulation of Money and Credit. Bettina Bieu Greaves, trans. (Dobbs Ferry, N.Y.: Free Market Books. p. 22)

M. Malkawi. (2008). Essay on Virtual Economy: Root cause analysis of the current financial crisis.

Martin T. Bohl., \& Janusz Brzeszczy'nski. (2006). Do institutional investors destabilize stock prices? Evidence from an emerging market. International Financial Market Institutions and Money, 16, 370-383. http://dx.doi.org/10.1016/j.intfin.2005.05.005

P. A. Samuelson. (1969). The way of an economist. Proceedings of the Third Congress of the International Economic Association, Macmillan, London.

Parsons, J. E. (1988). Bubble, bubble, how much trouble? Financial markets, capitalist development and capitalist crises. Science and Society, 52, 260-289.

Rüdiger D. (1990). Macroeconomics (5th ed.). New York: McGraw-Hill.

Roberts, David. (2006). British hit singles \& albums (19th ed.). London: Guinness World Records Limited.

Robbins. (1932). Essay on the nature and significance of economic science (1st ed.). London: Macmillan.

Robert I. (2007). Yes! It really is gambling. Economics, 2, 35-37.

Robert B., Hamid M., \& Paul Schultz. (2011). Market declines: Is banning short selling the solution? Federal Reserve Bank of New York Staff Reports, No. 518.

Sanjai B., \& Roberta Romano. (2007). Empirical studies of corporate law. Handbook of Law and Economics, 2.

S. Ross. (1976). The arbitrage theory of capital asset pricing. Journal of Economic Theory. 1(3), 341-360. http://dx.doi.org/10.1016/0022-0531(76)90046-6

Shiller, R. (2000). Irrational Exuberance (1st ed.). Princeton University Press.

S. J. Chang. (1990). Stock market in South Korea: Its volatility, dependency, and growth. Global Finance Journal, 1(3), 235-253. http://dx.doi.org/10.1016/1044-0283(90)90010-K

Stiglitz J. (2009). Global financial crisis causes and way forward. Paper presented to the United Nations General Assembly on the global repercussion of the crisis. Retrieved from http://www.un.org/ga/president/63/interactive/gsc.shtml

Thomas Lux. (1998). The socio-economic dynamics of speculative markets: interacting agents, chaos, and the fat tails of return distributions. Journal of Economic Behavior \& Organization, 33(2), 143-165. http://dx.doi.org/10.1016/S0167-2681(97)00088-7

Thom, R. (1975). Structural stability and morpohogenesis. Benjamin, New York: Westview Press.

Ujo Goto., \& C. R. McKenzie. (2001). An event study of environmentally conscious shareholders in the Japanese power industry. Environmental Modeling \& Software, 16(6), 517-524. http://dx.doi.org/10.1016/S1364-8152(01)00021-4

Wareen B. (2002). Berkshire Hathaway annual report. Retrieved from 
http://www.berkshirehathaway.com/2002ar/2002ar.pdf

W. Max Corden. (2009). The world credit crisis: Understanding it, and what to do. The World Economy, 385-400. http://dx.doi.org/10.1111/j.1467-9701.2009.01165.x

W. F. Sharpe. (1964). Capital asset prices: a theory of market equilibrium under conditions of risk. Journal of Finance, 19, 425-442.

Zeeman, E. C. (1974). On the unstable behavior of stock exchanges. Journal of Mathematical Economics, 1(1), 39-49. http://dx.doi.org/10.1016/0304-4068(74)90034-2

\section{Notes}

Note 1. Economic Insanity: How Growth-driven Capitalism is devouring the American Dream (1995) by Roger Terry. Published by Berrett-Koehler, San Francisco, pp. 1-2.

Note 2. Ghent, W. J. (1905). Lincoln and the Social Problem. Collier's, 35, 23-24.

Note 3. Niall Ferguson (December, 2008). Wall Street Lays Another Egg, Vanity Fair

Note 4. Niall Ferguson (December 2008). Wall Street Lays another Egg, Vanity Fair.

Note 5. Quotation of inaugural speech by US president Barak Obama from http://www.msnbc.msn.com/id/28751183/

Note 6. Declaration of G20. Retrieved on $27^{\text {th }}$ Feb 2009 from Whitehouse.gov.

Note 7. This information has been condensed form the URLs of various site including BBC, CNN, Bloomberg, wikipedia.

Note 8. http://en.wikipedia.org/wiki/Subprime_mortgage_crisis\#Regulatory_proposals_and_long-term_solutions

Note 9. Retrieved on $26^{\text {th }}$ June 2009 from http://www.toptenreviews.com/2-6-04.html

Note 10. Retrieved and calculated on $26^{\text {th }}$ June 2009 form http://en.wikipedia.org/wiki/List_of_countries_by_GDP (nominal).

Note 11. Retrieved on $26^{\text {th }}$ June 2009 from http://go.worldbank.org/LJA29GHA80.

Note 12. Retrieved on $9^{\text {th }}$ April 2012 from http://costofwar.com

Note 13. Utopian in this sense that one man's freedom is another man's slavery. Moreover more than 3 billion people lives at less than $\$ 2$ per day and thus has not economic freedom or during the meltdown of US financial system, the US financial markets were not allowed to work freely.

Note 14. This information has been condensed form the URLs of various site including BBC, CNN, Bloomberg, wikipedia.

Note 15. Please consider a synonymous example of a matchmaker who earns by matching a potential bride and bridegroom. What we would be expecting him to say about the bride to the guardian of the bridegroom or vice-versa?

Note 16. A leading case in common law is Salomon v. Salomon \& Co. [1897] AC 22.

Note 17. Kheyar means condition to change the terms of sales even after contact with the permission of both parties.

Note 18. David Gow (Oct, 2008). If you try to control everything it would probably kill capitalism, Guardian, Retrieved from http://business.guardian.co.uk/story/0,,2182836,00.html

Note 19. Nicolas Sarkozy (2008). "laissez-faire" finished'. Retrieved form www.volunteertv.com/international/headlines/29762874.html

Note 20. The Times (Oct, 2008). Retrieved from http://business.timesonline.co.uk/tol/business/markets/russia/article4863967.ece

Note 21. George Soros is having a Very Good Financial Crisis AMERICAN DREAMER. Retrieved from http://usdreamer.blogspot.com/2009/03/george-soros-is-having-very-good.html

Note 22. Khondoker Ibrahim Khaled (2011). Probe committee report of Dhaka Stock Exchange scam.

Note 23. Husat means trading something which cannot be specifically measured in terms of price, quantity, quality and dates etc.

Note 24. Retrieved from http://en.wikipedia.org/wiki/Commodity_Futures_Modernization_Act_of_2000 
Note

25.

Retrieved

from

http://eldib.wordpress.com/2009/03/12/global-derivatives-market-now-valued-at-11-quadrillion-do-you-wonder

Note 26. Barrett Sheridan (Oct 2008). It's a number no one questions, but the size of the derivatives market is not as shocking as it looks, Newsweek. Retrieved from http://www.newsweek.com/id/164591

Note 27. University of Maryland (June 2010). The role of Derivatives in the Global Financial Crisis. Retrieved from http://www.oea.umaryland.edu/communications/news?ViewStatus=FullArticle\&articleDetail=9855

Note 28. Bank for international settlements, Monetary and Economic Department, 'Survey of Foreign Exchange and Money supply, Switzerland.

Note 29. Information gathered from various pages of wikipedia including http://en.wikipedia.org/wiki/Gold_standard

Note 30. Stunner: Gold Standard Fully Supported By... Alan Greenspan!? Retrieved from http://www.zerohedge.com/article/stunner-gold-standard-fully-supported-alan-greenspan

Note 31. One may question that this will create intermediation problem as solved by current banking system. This is absolutely not true, as an analogy to banking system; even before the match making firms were there in human history, man did married to women. 